\title{
The FASTSIM Method Modification to Speed up the Calculation of Tangential Contact Stresses between Wheel and Rail
}

Tomáš Lack, Juraj Gerlici

University of Žilina, Faculty of Mechanical Engineering, Department of Transport and Handling Machines, Univerzitná 1, 01026 Žilina, tel.: +421 (41) 513 2664, e-mail: tomas.lack@fstroj.uniza.sk

The articles deals with the way of calculation of tangential stresses over non-elliptical contact patch, where is possible to utilize with advantage the Kalker's simplified method FASTSIM. This method named FASTSTRIP is adapted for non-elliptical contact area calculated by means of the Strip method. This method is almost quick as FASTSIM and the results are similar to the CONTACT results. This method may be useful for rail vehicles in track dynamics computation.

Keywords: tangential contact, strip method, FASTSIM, contact patch, Kalker method, FASTSTRIP

\section{Acknowledgement}

The work was supported by the Scientific Grant Agency of the Ministry of Education of the Slovak Republic and the Slovak Academy of Sciences in project No. 1/1098/11: "Stress Distribution in a Braked Railway Wheel". No. 1/0347/12: "Railway wheel tread profile wear research under the rail vehicle in operation conditions simulation on the test bench", project No. 1/0383/12: "The rail vehicle running properties research with the help of a computer simulation." and the project No. APVV-0842-11: "Equivalent railway operation load simulator on the roller rig".

\section{Research-Educational Center of Rail Vehicles (VVCKV)}

\section{References}

[1] JOHNSON, K., L. (1987) Contact Mechanics. Cambridge University Press Cambridge, p. 510.

[2] LACK, T, GERLICI, J. (2005) Contact Area and Normal Stress Determination on Railway Wheel / Rail Contact, Communications, Scientific Letters of the University of Žilina, vol.7(2), (p.38-45).

[3] KALKER, J., J. (1982) A fast Algorithm for Simplified Theory of Rolling Contact. Vehicle Systems Dynamics 11 (1982), pp.1-13.

[4] KALKER, J., J. (1990) Three-dimensional Elastic Bodies in Rolling Contact. Kluwer Academic Publishers, Dordrecht, Netherlands.

[5] KNOTHE, K., HUNG, L.-T. (1983) Ermittlung der Normalspannungs-verteilung beim Kontakt von Rad und Schiene. Forsch. Ing.-Wes. 49 (1983), (p.79-83).

[6] GERLICI, J., LACK, T. (2009) Strip Method Modification for Stresses in a Wheel / Rail Contact Computation. (In Slovak). Proceedings of the $7^{\text {th }}$ International Conference Dynamics of Rigid and Deformable Bodies 2009, Ústí nad Labem.

[7] LACK, T., GERLICI, J. (2011) Contact Stresses between Railway Wheel and Rail Computation by means of Strip Method Optimized Procedure. (In Slovak). Proceedings of the $9^{\text {th }}$ International Conference Dynamics of Rigid and Deformable Bodies 2011, Ústí nad Labem.

[8] GERLICI J., LACK, T. et al. (2005) Transport Means Properties Analysis - Vol. I, ISBN 80-8070-408-2. EDIS Publishing house of University of Žilina, (p.214).

[9] LACK, T, GERLICI, J. (2013) Wheel/Rail Contact Stress Evaluation by Means of the Modified Strip Method. In: Communications: Scientific Letters of the University of Žilina. - ISSN 1335-4205. - Vol. 15, no. 3 (2013), (p.126132).

[10] LACK, T, GERLICI, J. (2012) Wheel / Rail Contact Stress Evaluation by Means of the Modified Strip Method Utilization (2012). In: Proceedings of VSDIA 2012: 13th Mini conference on Vehicle System Dynamics, Identification and Anomalies 2012, Abstracts. Budapest, (p.23).

[11] LACK, T, GERLICI, J. (2011) Contact Stresses between Railway Wheel and Rail Computation by Means of Strip Method Optimized Procedure. (In Slovak). Proceedings of the $9^{\text {th }}$ International Conference Dynamics of Rigid and Deformable Bodies 2011, ISBN 978-80-7414-376-2. CD-ROM, Ústí nad Labem, (p.10).

[12] GERLICI, J., LACK, T. (2011) Railway Wheel and Rail Head Profiles Development Based on the Geometric Characteristics Shapes. Wear Vol. 271, No. 1-2 Sp. iss. (2011), (p.246-258). 
[13] GERLICI, J., LACK, T. (2010) Contact Geometry Influence on the Rail / Wheel Surface Stress Distribution, Procedia Engineering Vol. 2, Iss. 1 (2010), (p.2249-2257).

[14] SHACKLETON, P., IWNICKY, S. (2008) Vehicle System Dynamics, vol. 46(1-2), (2008), (p.129-149).

[15] LACK, T. GERLICI, J. (2012) Modified Strip Method Utilization for Wheel /Rail Contact Stress Evaluation. 9th International Conference on Contact Mechanics and Wear of Rail/ Wheel Systems (CM2012): Southwest Jiaotong University, 2012. Presented in Chengdu, China 2012.

[16] LACK, T, GERLICI, J. (2013) Tangential Stresses Evaluation over non-elliptical Rail /Wheel Contact Patch. In: Proceedings of the Conference: Dynamics of Rigid and Deformable Bodies 2013, ISBN 978-80-7414-607-7, CDROM, Ústí nad Labem, FVTM UJEP, (p.8).

[17] LACK, T, GERLICI, J. (2013) Tangential Stresses for non-eliptical Contact Patch Computation by Means of Modified FASTIM Method. In: IAVSD 2013: 23rd International Symposium on Dynamics of Vehicles on Roads and Tracks 2013, Qingdao, China, Chengdu Southwest Jiaotong University, (p.6).

[18] LACK, T, GERLICI, J. (2013) Tangential Stresses for Non-elliptical Contact Patch Evaluation by Means of modified FASTSIM Method In: Proceedings of XXXIX International Conference of the Transport, Handling, Civil and Agricultural Machines, ISBN 978-80-248-3124-4. CD-ROM, Ostrava: ID FS VSB - TU Ostrava, (p.9). 